\title{
Passiflora kikiana, a new species of Passifloraceae from the Brazilian Amazon
}

\author{
Armando Carlos Cervi ${ }^{1,3}$ and Leonardo von Linsingen ${ }^{2}$
}

Recebido em 7/05/2010. Aceito em 4/11/2010

RESUMO - (Passiflora kikiana, uma nova espécie de Passifloraceae da Amazônia brasileira). Uma nova espécie de Passifloraceae da Amazônia brasileira é descrita e ilustrada. Passiflora kikiana pertence ao subg. Passiflora, supersect. Passiflora, sect. Laurifolia, ser. Laurifoliae. Está proximamente relacionada a P. odontophylla e P. nitida; uma chave de identificação é apresentada para diferenciá-las.

Palavras-chave: Região Norte, Brasil, subgênero Passiflora, seção Laurifolia, taxonomia

ABSTRACT - (Passiflora kikiana, a new species of Passifloraceae from the Brazilian Amazon). A new species of Passifloraceae from the Brazilian Amazon is described and illustrated. Passiflora kikiana belongs to the subg. Passiflora, supersect. Passiflora, sect. Laurifolia, ser. Laurifoliae. It is closely related to $P$. odontophylla and P. nitida; a key to these species is provided.

Key words: Northern Brazil, subgenus Passiflora, section Laurifolia, taxonomy

The Passifloraceae comprise between 400 (Killip 1938; Cervi 1997, 2000) and 520 species (MacDougal \& Feuillet 2004), which are widely distributed throughout the Neotropics. Brazil is an important center of diversity of the family, where four genera and 138 species occur. Passiflora $\mathrm{L}$. is the most diverse genus of Passifloraceae in this country, where there are 129 native species (Cervi et al. 2010). This work describes and illustrates $P$. kikiana Cervi \& Linsingen, a new species from the Brazilian Amazon that belongs to subg. Passiflora, supersect. Passiflora, sect. Laurifolia (Cervi) Feuillet \& J.M. MacDougal, ser. Laurifoliae Killip ex Cervi (MacDougal \& Feuillet 2004).

\section{Passiflora kikiana Cervi \& Linsingen, sp. nov.}

Type: BRAZIL. Amazonas: Manaus-Porto Velho road, 3/

VI/1976, fl. fr., T.R. Bahia 93 (holotype UPCB; isotype IAN).

Passiflora kikiana Cervi \& Lisingen Passiflorae odontophyllae Harms ex Glaziou et P. nitidae Kunth affinis; a prima specie indumento puberulo, stipulis setiformibus asymmetricis, petiolo cum 2 vel 3 paribus glandulorum fungiformorum vel capitatarum, bracteis setiformibus, foliorum margine integro et corona quadrifaria distinguitur; a secunda pedunculis $3.5-3.7 \mathrm{~cm}$ longis, bracteis setiferis, petiolo 2 vel 3 paribus glandulorum, foliis e basi 5-nervis, corona quadrifaria et petalis rubris distinguitur.

Vines; stems cylindrical, minutely pubescent. Stipules $c$. $1.3 \times 0.3 \mathrm{~cm}$, membranous, arrow-shape, base asymmetric, with 3-5 glands along the margin, apex long-acuminate, hirsute. Leaves simple; petioles $2.5-2.8 \mathrm{~cm}$ long, with 2 or 3 pairs of fungiform or capitate glands; lamina 8.5-11 $\times 5-7$ $\mathrm{cm}$, membranous, ovate, base cordate, margin entire, apex acute, adaxially glabrous, abaxially pubescent, 5-nerved, actinodromous. Floral peduncle $3.5-3.7 \mathrm{~cm}$ long; pedicels $c$. $1 \mathrm{~cm}$ long; bracts 3 ( 2 opposed and 1 inserted above the other two), c. $1 \times 0.3 \mathrm{~cm}$, membranous, narrowly elliptical, apex acute, margin dentate. Flowers solitary or two per leaf axil, $5.5-6 \mathrm{~cm}$ diam.; calyx tube campanulate, $6-8 \mathrm{~mm}$ long, lobes $2.3-2.5 \times 0.6-0.9 \mathrm{~cm}$, membranous, lanceolate, obtuse at the apex, abaxially glabrous, greenish, adaxially reddish; petals red, the same size as the sepals; corona with 4 rows of filaments, the filaments in the outermost row reddish, subulate, $1.7-1.8 \mathrm{~cm}$ long, the filaments in the second row clavate at apex, c. $2 \mathrm{~mm}$ long, the filaments in the third row tuberculate, c. $1 \mathrm{~mm}$ long, the filaments in the innermost row filiform, clavate at apex, c. 5 $\mathrm{mm}$ long; operculum $c .1 .2 \mathrm{~cm}$ long, erect, with a membrane at the base and capitate filaments at the apex, the membrane $c .2$ $\mathrm{mm}$ long, with an adaxial tooth $c .1 \mathrm{~mm}$ long; limen $1.5-2 \mathrm{~mm}$ long, membranous, loosely surrounding the androgynophore; androgynophore $c .1 .6 \mathrm{~cm}$ long; ovary globose, glabrous. Fruits green-yellowish when mature, $4.5-5.5 \mathrm{~cm}$ diam., globose. Seeds brown, foveate; aril white, $c .5 \times 3 \times 2 \mathrm{~mm}$. Fig. 1

Additional specimens examined: BRAZIL. Acre: Manoel Urbano, 19/III/2002, fr., D.C. Daly et al. 11445 (NY, UPCB); Rio Branco, 19/V/1991, fr., C.A. Cid et al. 10107 $A$ (NY, UPCB); Rio Branco to Porto Velho, 4/II/1979, fl., fr., B.W. Albuquerque et al. 1332 (NY, UPCB). Amazonas: Manaus to Castanho, Km 18, 31/III/1985, fr., B. Nelson 1382 (INPA, MG, NY, UPCB). Pará: Santana do Araguaia, 18/II/1980, fr., T. Plowman et al. 8838 (MG, NY, UPCB).

Passiflora ser. Laurifoliae is characterized by being an herbaceous climber with cylindrical stems and tendrils; petioles and stipules with glands; entire or lobed leaves, which are glabrous to sparsely tomentose; three bracts subtending the pedicels; a campanulate calyx tube; a tubular or filamented operculum; and a membranous limen. Passiflora kikiana is morphologically similar to $P$. odontophylla Harms ex Glaziou and P. nitida Kunth, but they can be easily distinguished using the following key:

\footnotetext{
1 Universidade Federal do Paraná, Departamento de Botânica. Curitiba, PR, Brazil

2 Faculdade de Jaguariaíva, Setor de Ciências Agrárias, Engenharia Florestal. Jaguariaíva, PR, Brazil

Author for correspondence: accervi@ufpr.br
} 




Figure 1. Passiflora kikiana Cervi \& Linsingen: a. branch with flowers and a fruit; b. schematic detail of a longitudinal section of the flower; c. stipule; d. bract; e. petiole, showing the glands (holotype Bahia 93). 
1. Corona filaments arranged in many rows

P. odontophylla

1 '. Corona filaments in 4-6 rows.

2. Petiole with 1 pair of sessile glands, leaves slightly serrate along the margin P. nitida

2 '. Petiole with 2 or 3 pairs of fungiform or capitate glands, leaves entire P. kikiana

The specific epithet is in honor of the beautiful, lovely and dear granddaughter of the first author, Maria Francisca Cervi Sigel, who is affectionately called Kiki by her grandparents.

\section{Acknowledgments}

We thank William A. Rodrigues for the Latin diagnosis, Eric Camargo Smidt for reviewing the text, Antonio Dunaiski Jr. for the illustrations, and $\mathrm{CNPq}$ for the PQ grant awarded to the first author.

\section{References}

Cervi, A.C. 1997. Passifloraceae do Brasil: estudo do gênero Passiflora L. subgênero Passiflora. Fontqueria 45(1): 1-92.
Cervi, A.C. 2000. Estudo das passifloras brasileiras: o subgênero Dysosmioides Killip do gênero Passiflora L. para o Brasil. Estudos de Biologia 45: 91-115.

Cervi, A.C.; Milward-de-Azevedo, M.A. \& Bernacci, L.C. 2010. Passifloraceae. In: Lista de Espécies da Flora do Brasil. Rio de Janeiro, Jardim Botânico do Rio de Janeiro. http:// floradobrasil.jbrj.gov.br/2010/FB000182. (Accessed in 31/7/2010).

Killip, E.P. 1938. The American species of Passifloraceae. Field Museum of Natural History. Botanical Series 19(1-2): 1-613.

MacDougal, J.M. \& Feuillet, C. 2004. Systematics. Pp 27-31. In: Ulmer, T. \& MacDougal, J.M. (eds). Passiflora: passionflowers of the world. Portland, Timber Press. 